\title{
URBAN PUBLIC SATISFACTION WITH DRINKING WATER SINCE 2002 IN THE PACIFIC NORTHWEST, USA
}

\author{
R.L. MAHLER ${ }^{1}$, M.E. BARBER ${ }^{2} \&$ B. SHAFII ${ }^{3}$ \\ ${ }^{1}$ Soil and Environmental Sciences, University of Idaho, Moscow, Idaho, USA. \\ ${ }^{2}$ Department of Civil and Environmental Engineering, University of Utah, Salt Lake City, Utah, USA \\ ${ }^{3}$ Department of Plant, Soils and Entomological Sciences, University of Idaho, Moscow, Idaho, USA.
}

\section{ABSTRACT}

The purpose of this paper is to document drinking water issues and concerns of the urban public in the Pacific Northwest, USA. Urban residents of the Pacific Northwest region of the USA consider drinking water their most important water resource issue. A survey instrument was developed to measure urban satisfaction with drinking water supplies. Data were collected using mail-based surveys conducted at five-year intervals in 2002, 2007 and 2012. Each survey contained 11 questions about drinking water and was mailed to 2,200 randomly chosen residents of Alaska, Idaho, Oregon and Washington. Return rates in excess of 50\% were received for each survey ensuring that the results are statistically valid. On a regional basis $60.7,64.1$ and $68.8 \%$ of Pacific Northwest residents relied on public water supply systems for their drinking water in 2002, 2007 and 2012, respectively. This number increased to between 79\% (2002) and 86\% (2012) when only urban residents were considered. Over $86 \%$ of urban residents felt that water they obtained from the tap in their home was safe to drink. However, over $26 \%$ of survey respondents reported that they often used bottled water. Very little of this bottled water is consumed in the home and instead used more as a convenience rather than for health-related issues. Bottled water use significantly declined between 2007 and 2012. Almost one in four urban residents had a secondary water filter in their home. The use of in-home filters has increased significantly since 2002. Approximately $15 \%$ of survey respondents identified minerals (hard water) as a concern in their drinking water. However, other potential contaminants including pathogens, nitrates, pesticides and heavy metals were identified as problems by less than $5 \%$ urban residents. Overall, the urban public is satisfied that their home drinking water is safe; however, in the last 10 years there has been a trend toward more skepticism and additional in-home treatment of drinking water.

Keywords: Public opinion, drinking water issues, drinking water safety, adult education, public outreach, bottled water, home water treatment.

\section{INTRODUCTION}

A safe and plentiful water supply is widely considered to be a basic human right [1]. Several agencies within the United Nations suggest that each human needs in excess of 900,000 liters of water each year to meet their needs. However, most of this water is used in the production of food. Because of this, water is often indirectly obtained through the importation of food in the 50+ most waterscarce countries. Estimates of the minimum per capita water requirement vary widely [1]. Daily water requirements range from low values of 7-50 liters per capita per day $(1 / \mathrm{c} / \mathrm{d})$ to high estimates of between 1,369 and 4,654 1/c/d [2-7]. The 50-1/c/d basic water requirement covers the following four basic water needs: (1) drinking water for survival, (2) human hygiene, (3) sanitation services and (4) household food preparation [2]. From a drinking water standpoint, the average human should consume between 1.8 and $2.0 \mathrm{l} / \mathrm{d}[5,6,8]$.

Drinking water has been protected and treated to some extent by societies for over 5,000 years [9]. The ancient Mesopotamians were the first to link certain human activities with water that was unsafe for drinking. Later the Romans learned how to seek the best water sources, transport it to reservoirs, use sand filters to make it purer and then pipe it to fountains in cities where it could be conveniently accessed by the masses. Since the 1880s, many cities in Europe and North America have taken on 
the responsibility of providing safe drinking water for citizens first by filtration and then by chlorination to remove microbial pathogens. By the 1950s, guidelines for inorganic chemicals including nitrate- $\mathrm{N}$ and lead were developed. The explosion in the development and use of organic chemicals by industry and agriculture led to increased scrutiny and the development of standards by the 1970s. To further protect Americans, Congress passed the Safe Drinking Water Act of 1974. Consequently, both human-made and natural radionuclides were evaluated, and drinking water standards were developed. Finally, the clarity (turbidity) of surface waters used as drinking water was regulated.

Consumer satisfaction with drinking water has been measured in several studies [10-17]. However, many factors have been found to be involved in the public perception of drinking water quality [18-20]. Important factors involved in overall public perception include flavor, risk perception, attitudes toward chemicals often found in drinking water, trust in the public water supply system, past problems attributed to water quality and information provided by the local media [18,21-24]. Although all of the listed factors are important, the credibility of societal institutions providing the drinking water and the regulatory agency providing standards and enforcement for pathogens, inorganic chemicals, organic chemicals, radionuclides and turbidity are probably most important [13]. In recent years, US consumers have been able to purchase different quantities of bottled water whose quality is regulated by the United States Food and Drug Administration (USFDA). Over 20\% of consumers have opted for bottled water as an alternative to tap water, which is regulated by the United States Environmental Protection Agency (USEPA) [13,25,26]. In Canada, studies have shown that when consumers are dissatisfied with the tap water provided by municipalities they often turn to bottled water [15,27].

Many countries have developed safe drinking water strategies and standards that protect public health $[3,17,28]$. However, as populations in urban centers greatly expand over the next few decades, strategies, standards and risk assessments need improvement. Addressing this problem is most urgent in the developing world where there will be 16 cities with more than 10,000,000 residents by 2015 [29]. Urban consumers in many developed countries receive an annual report about their drinking water system; however, research has shown that one report is not enough to effectively change public perception [30]. In addition, qualitative reports to consumers affect public perception less than quantitative reports. Municipalities and educators have learned that it is not enough to just provide safe drinking water to consumers. The risk of underestimating public perceptions about water systems must not be dismissed [16]. Factors that are documented to influence public perception of drinking water and delineation of acceptable risk include (1) visibility of pollutants such as color, (2) personal use, (3) historical change from emphasis on pathogens to toxic chemicals, (4) consumer education level, (5) consumer age, (6) trust in public officials, (7) public involvement in decisionmaking processes, and (8) poor risk communication efforts [31].

Since 1987, in the United States, an increased emphasis has been placed on public education as a mechanism to improve the nation's water resources through knowledge and voluntary actions. This idea has been implemented using a regional rather than a state-by-state approach. To accurately determine the effectiveness of regional programming, it is important both to establish base-line information about public perceptions and literacy, and then to measure change in public attitudes and actions over time. Furthermore, to identify the best opportunities for successful regional programming, it is imperative to understand the similarities and differences that exist among the target audiences. In the four-state (Alaska, Idaho, Oregon, Washington) Pacific Northwest Region, a survey instrument was developed to provide base-line information on public attitudes regarding water resources in 2002 from which future Extension programming outcomes can be measured [32,33]. This initial regional survey documented public attitudes about water resources in 2002. At that time 
it was anticipated that follow-up water resource surveys would be conducted at 5-year intervals for five periods $(2007,2012,2017,2022,2027)$. This paper evaluates information about public perceptions, attitudes and consumption of drinking water provided by public water systems in urban areas of the Pacific Northwest. This paper evaluates how the urban public views the quality of water delivered to the consumer by public municipalities.

\section{METHODOLOGY}

A survey instrument was developed to access public priorities, attitudes and concerns about water resource issues in the Pacific Northwest. The survey was administered to the general public in 2002, 2007 and 2012 to evaluate changes over time. The specific survey questions covered in this paper deal with responses to questions about drinking water. The public was asked the following drinking waterrelated questions: (1) How important is clean drinking water to you? (2) Where do you primarily get your drinking water? (3) Do you feel that your home drinking water is safe to drink? and (4) Do you have your home drinking water tested? In addition to those four specific questions, information was also collected about the following: (1) water softeners, (2) in-home water filters, (3) use of bottled water, (4) satisfaction with tap water, and (5) water system connections. The survey target audience was a representative sample of the 9,000,000 adult residents of the four Pacific Northwest states (Alaska, Idaho, Oregon, and Washington). Drinking water questions were asked of both urban and rural residents so that answers could be compared between these two demographic groups. In addition, demographic information, including state of residence, community size, length of time residing in the region, gender, age, and educational level were also collected from survey respondents.

In 2002, 2007 and 2012 a target of 950 completed questionnaires was chosen as the survey goal to result in a sampling error of 4-6\% [34]. The survey process was designed to receive a completed survey return rate in excess of 50\%. Addresses were obtained from a professional social sciences survey company (SSI, Norwich, CT, USA). Four mailings were planned to achieve the 50\% return rate [33]. The mailing strategy used was identical in all four survey years [35].

Surveys were actually sent to approximately 2,100 residents in each survey; however, because of address changes, deaths of people on the mailing list and delivery problems, the actual sample population was close to 1,900 . The survey process was designed to receive a completed survey return rate in excess of 50\%. If more than 960 surveys were returned completed, then sampling error could be assumed to be less than 5\% [34-36]. The survey respondents came from the same sample each five-year study period; however, the actual surveyed individuals differed.

It took three (2012) to four $(2002,2007)$ mailings to achieve this target return rate of at least $50 \%$. For each survey year, the first mailing included the water issues survey form, a business reply envelope, and a cover letter that (1) identified the survey's authors; (2) explained the purpose of the survey; (3) assured the respondent of anonymity; and (4) asked the respondents to fill out and return the survey via the business reply envelope. The second mailing occurred five weeks later and consisted of a postcard that stressed the importance of the survey and remind the respondent to fill out and return the survey sent out in the first mailing. Five weeks later the third mailing was sent to residents who did not respond to the first or second mailing. This mailing included a reminder letter, another copy of the water issues survey, and a business reply envelope. A fourth mailing consisting of a reminder postcard follow-up five weeks later was used in the 2002 and 2007 surveys to achieve the $50 \%$ response rate.

Survey answers for each 2002, 2007 and 2012 were coded and entered into Microsoft Excel. Missing data were excluded from the analysis. Data were evaluated from only the respondents who could be identified as urban. Thus the data from respondents living in rural areas was excluded from 
analysis. The data were analyzed at two levels using SAS [37]. The first level of analysis generated frequencies, whereas the second level evaluated the impacts of demographic factors. Significance $(\mathrm{p}<0.05)$ to demographic factors was tested using a Chi-square distribution [37].

\section{RESULTS AND DISCUSSION}

The survey methodology used in the study was not designed to be unique, but rather to be used as a tool to ascertain useful information. The survey methodology is designed to point out the strengths and weaknesses of drinking water delivered by municipalities to urban consumers and the perceptions and misconceptions of the consumers in the Pacific Northwest. Appropriate education programs will be developed for Pacific Northwest audiences based on this information.

The 2002, 2007 and 2012 Pacific Northwest Water Issues Survey achieved a return rate of 56.1, 55.3 and $54.1 \%$, respectively. When the three surveys were averaged, it was determined that $54 \%$ of the survey respondents were male. Over $38 \%$ of survey respondents lived in communities of more than 100,000 people. Conversely, $16 \%$ of respondents lived in towns with less than 7,000 people. Forty-one percent of respondents had lived in the Pacific Northwest all of their lives. Eighty-seven percent of survey respondents were high school graduates. Overall, the demographics of the survey respondents (except for gender) closely reflected the actual demographics of the region. Consequently, when coupled with the low sampling error of the survey, respondents are often equated to residents in the following discussion.

When the three surveys were pooled approximately $71 \%$ of the responses came from urban residents. Consequently, these study results focus on this distinctly urban group. This $71 \%$ portion actually correctly mirrors the actual percent of urban residents of the region.

\subsection{Source of drinking water}

Since 2002 surveys have shown that $99 \%$ of urban residents of the Pacific Northwest consider safe drinking water to be a very or extremely important issue $[10,16]$. In fact these residents rank safe drinking water as the most important environmental issue affecting them (data not shown).

On a regional basis $60.7,64.1$ and $68.8 \%$ of Pacific Northwest residents relied on public water supply systems for their drinking water in 2002, 2007 and 2012, respectively (Fig. 1). This number increased to between 79 (2002) and $86 \%$ when only urban residents were considered. When the 'other/don't know' responses are eliminated virtually $94 \%$ of urban residents depended on municipal public water supply systems. This number reported in 2012 (94\%) is statistically similar to survey values obtained the in 2002 and 2007 regional surveys [38].

In addition to the source of drinking water survey, respondents were asked to indicate (by checking) the following items that applied to drinking water in their home: I have a water softener (Water softener); I have a water filter (Water filter); I purchase 5 gallon containers of drinking water (Five gallon purchases; I often use bottled water for drinking purposes (Use bottled water); I never buy bottled water (Never use bottled water); I am satisfied with my drinking water - piped into house (Satisfied with DW); I am not satisfied with my drinking water - piped into house (Not satisfied with DW); and my drinking water is separate from my water supply system (Separate water system).

Significant interactions for each survey drinking water question between where respondents lived (WL), town size (TS), length of time living in the Pacific Northwest (PNW), gender (GDR), age (AGE) and formal education level (ED) are discussed in later sections of this paper. Age and formal education level were the demographic factors that most often affected responses to drinking water questions. 


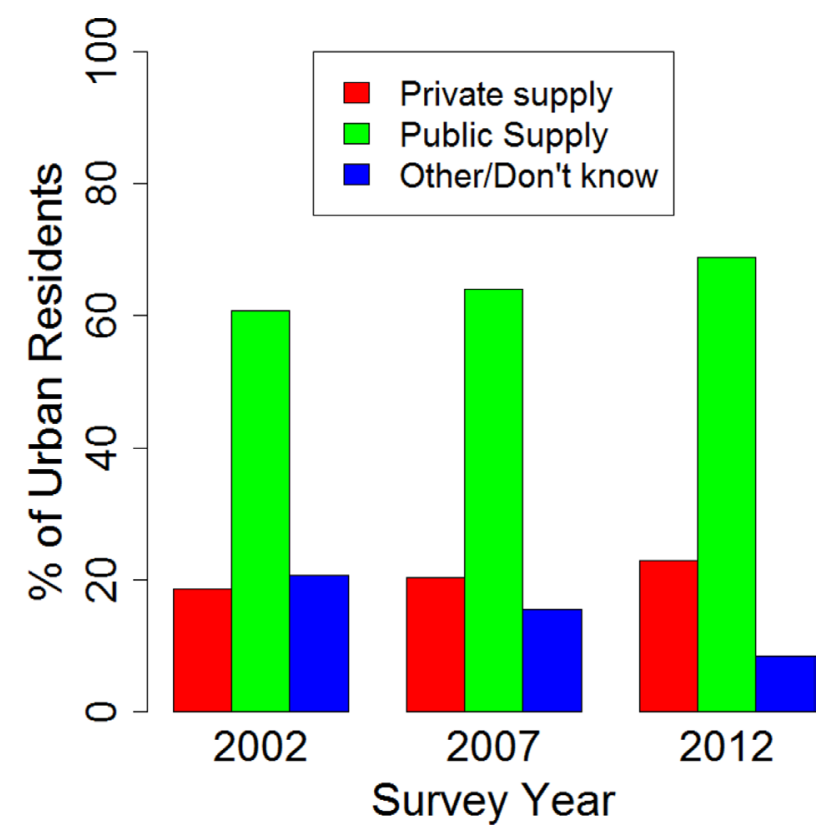

Figure 1: Primary source of drinking water for residents of the Pacific Northwest based on 2002, 2007 and 2012 PNW Surveys.

\subsection{Safe drinking water}

Over 92,90 and $86 \%$ of survey respondents in 2002, 2007 and 2012, respectively, felt that water they obtained from the tap in their home was safe to drink (Fig. 2). There were, however, interactions with gender, age and education level of the respondents. Even though a large majority of the surveyed residents felt that their drinking water was safe, there is a statistical difference between survey years - more respondents felt that their drinking water was safe in 2002 than in 2012 $(0.04 *)$.

Males were more likely to consider their home tap water safe to drink than females $(92.4 \%$ vs. $81.2 \%$ ). Age had a significant impact on the response to the safety of drinking water at the tap in 2007 and 2012 (Table 1). In both the years, respondents younger than 40 years of age were less likely to consider their home tap water safe to drink than older respondents. Conversely, age did not affect the response to drinking water safety in 2002. Although a statistical difference existed between the less than 40 years and more than 40 years age groups, it should be pointed out that the vast majority of urban respondents considered their tap water safe in all three survey years.

Formal education level of the survey respondents affected the response to the safety of home drinking water at the tap (Table 2). In all three surveys, the more formally educated the respondent, the more likely water at the tap was considered safe to drink. Here, the older the survey respondent, the more likely water at the tap was considered safe to drink in $2002(0.03 *), 2007$ $(0.01 * *)$ and $2012\left(0.005^{* *}\right)$. Again, even though there was a statistically significant difference due to education level, the overwhelming majority of urban residents considered water at the tap safe to drink. 


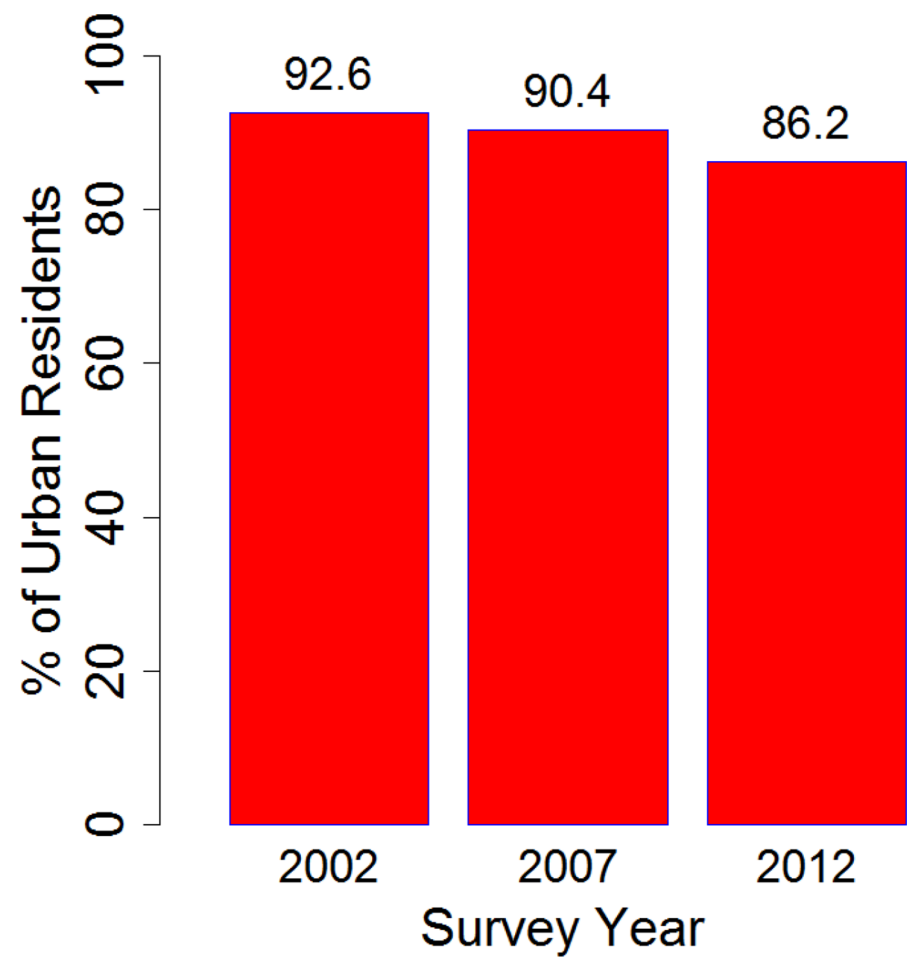

Figure 2: Urban residents who considered drinking water from the tap safe to drink based on 2002, 2007 and 2012 PNW Surveys.

Table 1: Interaction between saying tap water is safe to drink and respondent age based on 2002, 2007 and 2012 PNW Surveys.

\begin{tabular}{llll}
\hline Respondent age (years) & 2002 & 2007 & 2012 \\
\hline Less than 30 & 86.4 & 83.4 & 79.1 \\
30-39 & 85.2 & 83.7 & 80.4 \\
$40-49$ & 91.4 & 90.4 & 85.6 \\
$50-59$ & 84.3 & 92.4 & 88.6 \\
$60-69$ & 92.3 & 94.0 & 87.8 \\
More than 70 & 91.6 & 91.5 & 87.0 \\
Significance & & & $0.006^{* *}$ \\
\hline
\end{tabular}

In many situations, water safety and water satisfaction are not necessarily the same. Here in the Pacific Northwest well over two-thirds of urban survey respondents were satisfied with their drinking water in 2002, 2007 and 2012. An interaction between drinking water satisfaction and respondent educational level was observed in 2007 and 2012, but not in 2002 (Table 3). Respondents without a high school diploma were less likely to be satisfied with their drinking water in 2007 and 
Table 2: Interaction between saying that tap water is safe to drink and formal educational level of respondents based on 2002, 2007 and 2012 PNW Surveys.

\begin{tabular}{llll}
\hline Respondent education level & 2002 & 2007 & 2012 \\
\hline Less than high school diploma & 83.0 & 83.9 & 79.1 \\
High school diploma & 83.5 & 82.9 & 80.1 \\
Some college & 89.2 & 89.7 & 84.8 \\
College graduate & 95.6 & 95.3 & 89.5 \\
Advanced college degree & 96.3 & 95.7 & 90.6 \\
Significance & $0.03^{*}$ & $0.01^{* *}$ & $0.005^{* *}$ \\
\hline
\end{tabular}

Table 3: Interaction between likelihood of being satisfied with their drinking water and formal educational level of respondents based on 2002, 2007 and 2012 PNW Surveys.

\begin{tabular}{llll}
\hline Respondent education level & 2002 & 2007 & 2012 \\
\hline Less than high school diploma & 60.5 & 54.5 & 55.6 \\
High school diploma & 70.3 & 60.4 & 71.9 \\
Some college & 62.4 & 69.1 & 65.0 \\
College graduate & 71.3 & 78.2 & 73.4 \\
Advanced college degree & 70.6 & 76.6 & 78.3 \\
Significance & NS & $0.02^{*}$ & $0.04 *$ \\
\hline
\end{tabular}

2012 (Table 3). Even though this statistical difference was observed, the main point of the survey data is that there is widespread satisfaction with drinking water in urban areas of the Pacific Northwest. Hence, at least in the Pacific Northwest most urban residents equate safe drinking water with drinking water satisfaction.

\subsection{Bottled water}

Over 28, 34 and 26\% of survey respondents reported that they often use bottled water in 2002, 2007 and 2012, respectively (Fig. 3). Very little of this water is consumed in the home; however, as many of the positive respondents often travel with bottled water. Consequently, they use bottled water more as a convenience rather than for health-related issues. Bottled water use significantly declined between 2007 and 2012 (Fig. 3). This may be due to at least two different reasons. First, educational programs to show the similarity in safety of tap water compared with bottled water may have impacted use. Second, waste reduction advocates have targeted the plastic bottles often associated with bottled water as wasteful - and a segment of the public in the region has responded to this educational effort.

Interactions were observed between bottled water use and the demographic factors of age and education level. Age affected the use of bottled water in all three survey years (Table 4). In general, respondents older than 49 years of age were less likely to use bottled water than younger respondents 


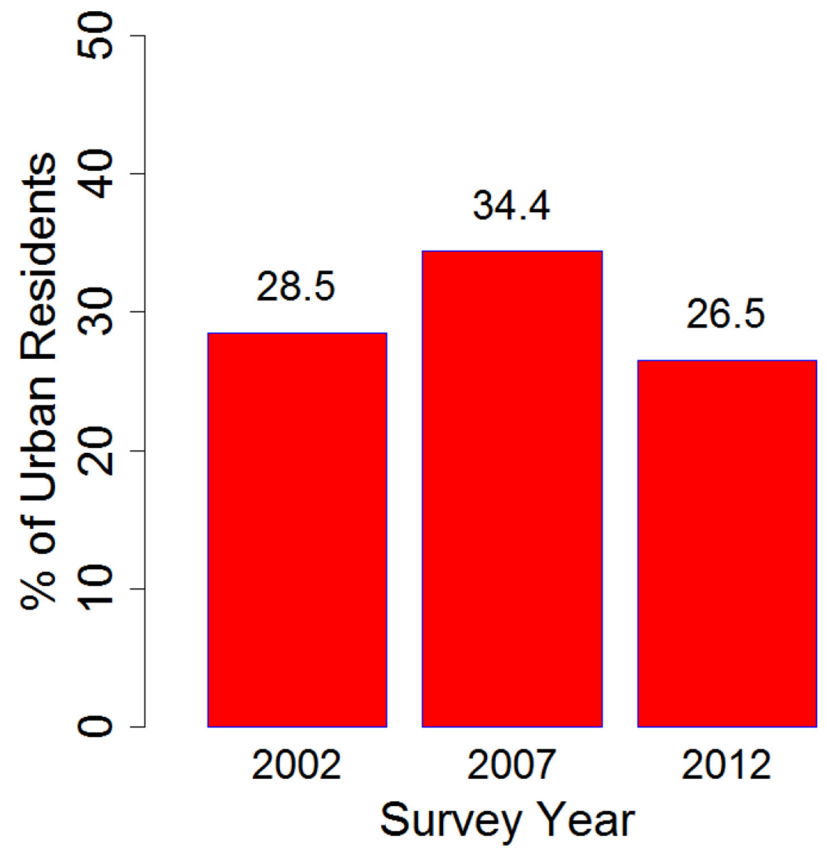

Figure 3: Urban residents who used bottled water on a regular basis for drinking and/or convenience based on 2002, 2007 and 2012 PNW Surveys (significance level $=0.01 * *$ ).

Table 4: Interaction between often using bottled water and respondent age based on 2002, 2007 and 2012 PNW Surveys.

\begin{tabular}{llll}
\hline Respondent age (years) & 2002 & 2007 & 2012 \\
\hline Less than 30 & 30.2 & 36.7 & 38.3 \\
30-39 & 32.3 & 35.5 & 25.6 \\
$40-49$ & 39.6 & 51.5 & 43.5 \\
50-59 & 24.3 & 29.0 & 19.2 \\
60-69 & 25.0 & 27.9 & 26.4 \\
More than 70 & 18.6 & 24.4 & 20.7 \\
Significance & & & $0.001 * * *$ \\
\hline
\end{tabular}

in all three surveys. This can be explained by the observation that many older Pacific Northwest urban residents grew up without access to bottled water and consequently were more likely to choose bottled water as an alternative. Basically they did not have a compelling reason to seek an alternative source of drinking water.

Formal education level also impacted the use of bottled water by urban consumers in the Pacific Northwest in 2007 and 2012, but not in 2002 (Table 5). College graduates with four-year and 
Table 5: The influence of formal education level on the likelihood of often using bottled water based on 2002, 2007 and 2012 PNW Surveys.

\begin{tabular}{lccc}
\hline Respondent education level & 2002 & 2007 & 2012 \\
\hline & $\%$ using & \% using & \% using \\
& 28.5 & 38.7 & 29.6 \\
Less than high school diploma & 31.6 & 34.3 & 29.7 \\
High school diploma & 30.4 & 42.4 & 32.9 \\
Some college & 27.5 & 27.7 & 23.4 \\
College graduateAdvanced college & 27.0 & 26.6 & 17.2 \\
degreeSignificance & NS & $0.001^{* * *}$ & $0.008^{* *}$ \\
\hline
\end{tabular}

advanced degrees were less likely to use bottled water than consumers with some college, a high school diploma or less than a high school diploma (Table 5). These observed differences in 2007 and 2012 due to formal education level is likely due to the more educated consumers knowing that their tap water is at least as safe as bottled water. The educated consumers were more likely to be aware of the Safe Drinking Water Act of 1974.

\subsection{In home water filters}

Over $21,26 \%$ and $34 \%$ of urban residents had a secondary water filter in their home based on the 2002, 2007 and 2012 surveys, respectively (Fig. 4). The use of in-home filters increased in 2007 compared with 2002 and in 2012 compared with $2007(0.02 *)$. Most of these filters are either located on the kitchen sink faucet or the filter is in a small stand-alone device coupled with a water pitcher. The stand-alone pitcher device can be placed in the refrigerator to supply drinking water at the consumer's convenience. Consumers use filters because they believe that these devices improve the taste of municipally supplied drinking water.

The demographic factor of respondent age affected the use of in-home water filters in urban areas of the Pacific Northwest. This age effect was striking as the use of an in-home water filter decreased with increasing age in 2002, 2008 and 20012, respectively (Table 6). Residents in the 60+ age groups were less likely to have a filter - probably because they were satisfied with the tap water they were raised with and had no real reason to seek additional treatment.

Although not a water filter, almost $15 \%$ of urban residents had water softeners to reduce levels of calcium, magnesium and/or iron in their home water supply based on the 2002, 2007 and 2012. Differences due to survey year were not observed. This treatment of hard water would improve the bathing and laundry aspects of their water supply.

\subsection{Water testing}

Between 18 and $22 \%$ of urban residents had their water tested on a regular basis in the surveyed years (Fig. 5). Statistical differences due to survey year were not observed. Community size impacted a respondents' answer to this question. When both the urban and rural responses were considered 


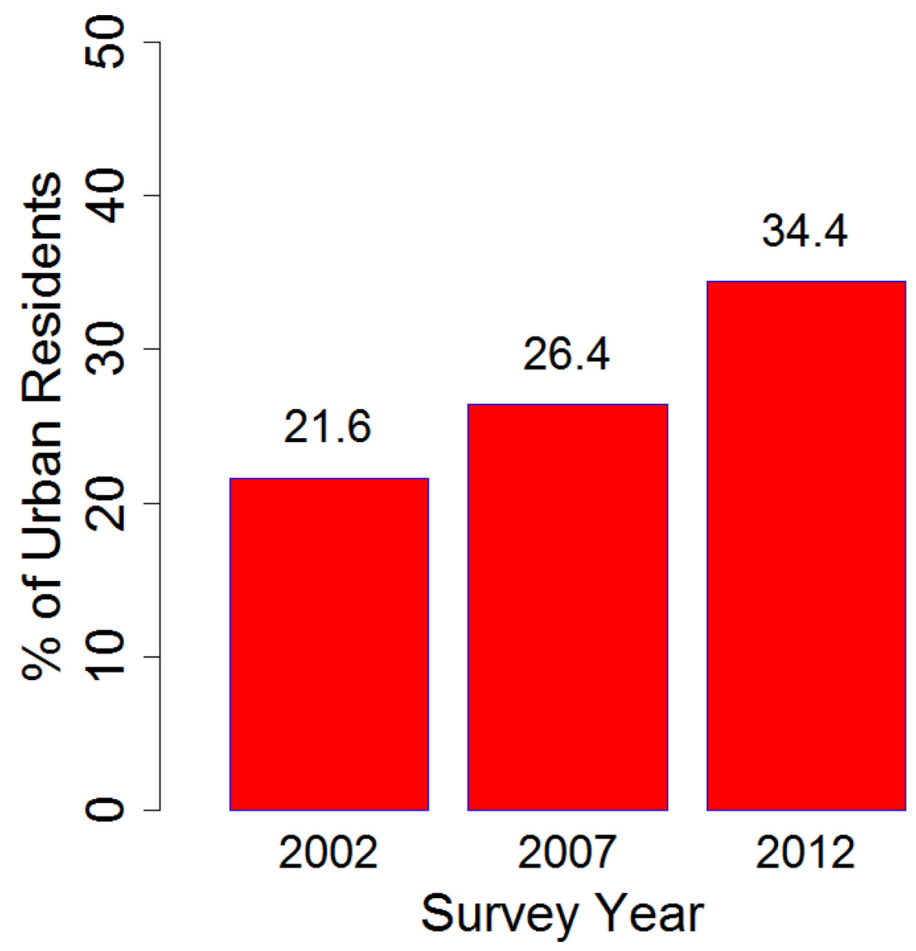

Figure 4: Urban residents who have installed a secondary water filter in their home based on 2002, 2007 and 2012 PNW Surveys (significance level $=0.02 *$ ).

Table 6: The influence of respondent age on having a water filter in the house/kitchen based on 2002, 2007 and 2012 PNW Surveys.

\begin{tabular}{lccc}
\hline Respondent age (years) & 2002 & 2007 & 2012 \\
\hline & \% having & \% having & \% having \\
Less than 30 & 25.2 & 34.2 & 44.7 \\
30-39 & 27.9 & 30.5 & 44.1 \\
40-49 & 24.6 & 28.4 & 42.6 \\
50-59 & 19.4 & 26.4 & 40.9 \\
60-69 & 16.2 & 19.4 & 31.3 \\
More than 70 & 12.1 & 16.8 & 24.6 \\
& & & \\
Significance & $0.008 * *$ & $0.02 *$ & $0.001 * *$
\end{tabular}




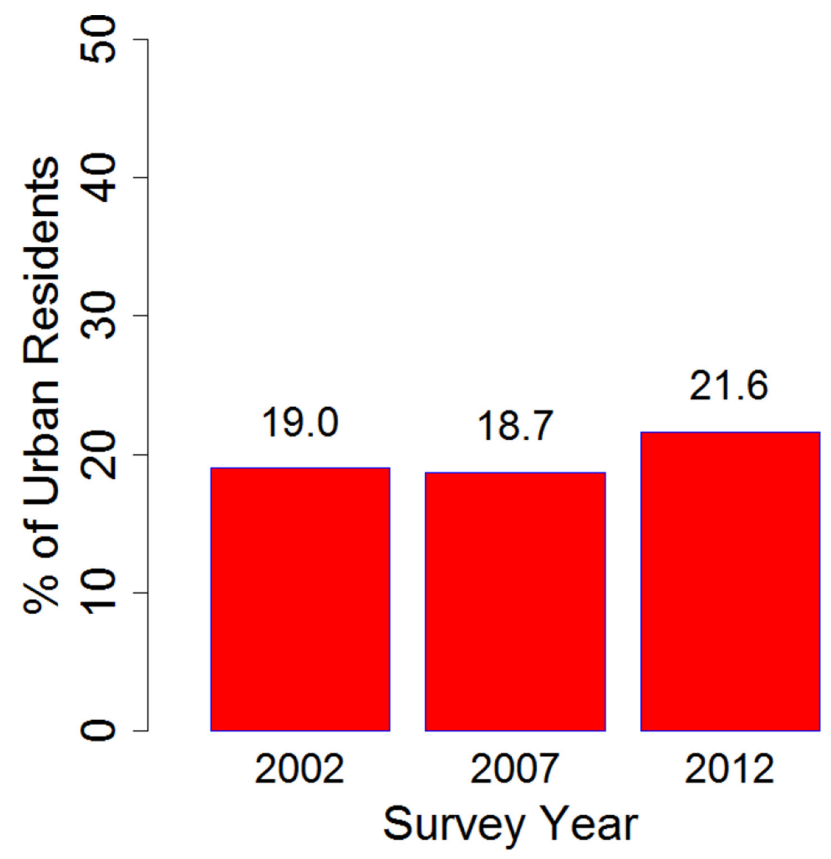

Figure 5: Urban residents in communities with more than 100,000 people who have their water tested on a regular basis based on 2002, 2007 and 2012 PNW Surveys (significance level = NS).

residents of towns with more than 25,000 people were less likely to have their water tested on a regular basis (Table 7). Basically, city residents expect that their public water system will do all the testing required to ensure that their drinking water is safe. Conversely, people in the rural areas understand that in many situations the individual is responsible for water safety. Consequently, they are more likely to have their water tested. Samples from home drinking water samples were sent to laboratories to be tested by $17.9,32.0$ and $44.0 \%$ of survey respondents living in city limits, outside of city limits (non-farm), and on-farms, respectively.

\subsection{Water contaminants}

Urban residents were asked to rate their concern about specific contaminants in their drinking water supply in 2002, 2007 and 2012. The specific contaminants evaluated in the survey included bacteria (pathogens), nitrates, pesticides, heavy metals, industrial chemicals and minerals (hard water). Approximately $15 \%$ of survey respondents identified minerals (hard water) as a concern in their drinking water. However, other potential contaminants were identified as problems less than $5 \%$ of the time. The ranking of these contaminants from highest potential problem to lowest (top five rated) is shown in Table 8 .

It is important to note that minerals (hard water) was ranked as having the highest level of concern in all three surveyed years as between 14 and $22 \%$ of surveyed respondents identified it as an issue of concern. Items ranked from number two to number five are of minor importance because between only 1.5 and $3.5 \%$ of surveyed respondents identified these contaminants as issues in their drinking 
Table 7: Interaction between having a water filter in the house/kitchen and community size based on 2002, 2007 and 2012 PNW Surveys.

\begin{tabular}{lccc}
\hline Community size & 2002 & 2007 & 2012 \\
\hline & $\%$ using & $\%$ using & \% using \\
100,000 or more & 19.0 & 18.7 & 21.6 \\
25,000 to 99,999 & 21.4 & 22.4 & 18.8 \\
7,000 to 24,999 & 20.2 & 22.9 & 29.9 \\
3,500 to 6,999 & 27.3 & 27.1 & 38.3 \\
Less than 3,500 & 35.1 & 36.2 & 38.6 \\
Significance & $0.001 * * *$ & $0.003 * *$ & $0.001 * * *$ \\
\hline
\end{tabular}

Table 8: Drinking water contaminants most cited by urban residents to be of concern in their drinking water supplies in 2002, 2007 and 2009 based on PNW surveys.

\begin{tabular}{llll}
\hline Concern level & 2002 & 2007 & 2012 \\
\hline 1 (highest concern) & Minerals & Minerals & Minerals \\
2 & Industrials & Industrials & Pathogens \\
3 & Nitrates & Pathogens & Nitrates \\
4 & Pesticides & Pesticides & Pesticides \\
5 (lowest concern) & Pathogens & Nitrates & Industrials \\
\hline
\end{tabular}

water. This is important because the urban public could not identify any health-threatening contaminants as issues in their drinking water supplied by their municipality.

The identification of minerals (calcium, magnesium, iron and others) is not a health concern because these minerals fall into the secondary category of drinking water standards. Many residents who voiced concern about minerals have installed water softeners.

\subsection{Comparison with rural residents}

Based on survey results, rural residents of the Pacific Northwest have different priorities and beliefs about drinking water issues. These differences are highlighted in Table 9. Rural residents are more likely to get their drinking water from a private source such as a well. Because private wells are not regulated by the Safe Drinking Water Act of 1974, rural residents have to be more vigilant and proactive about their drinking water than urban residents.

Because of this, rural residents are more likely to consider their drinking water less safe and they tend to be less satisfied with their water. Despite this lower level of confidence, rural residents are much less likely to use bottled water. Compared with their urban counterparts, rural residents are more likely to (1) be concerned about contaminants in their drinking water, (2) have their water tested regularly, and (3) use an in-home water filter. Even though these differences between rural and 
Table 9: Compared with drinking water issues in urban areas, rural residents more likely to:

\begin{tabular}{ll}
\hline Issue & Rural residents were more likely to.... \\
\hline Drinking water source & Get drinking water from private wells \\
Drinking water safety & Consider drinking water less safe \\
Drinking water satisfaction & Be less satisfied with drinking water \\
Bottled water & Not use bottled water \\
In home water filter & Use an in house water filter \\
Water contaminants & Be concerned about contaminants \\
Water testing & Have their water tested regularly \\
\hline
\end{tabular}

urban water consumers in the Pacific Northwest, the majority of rural residents still consider their drinking water safe and satisfying.

\section{CONCLUSIONS AND RECOMMENDATIONS}

Urban residents of the Pacific Northwest appear to be satisfied with the drinking water supplied by public water systems. The majority of residents regularly drink their home tap water. Less than $35 \%$ of residents use in-home water filters, water softeners or bottled water. Age and formal education level often affected how citizens responded to drinking water questions. Older residents seemed more satisfied with their home drinking water; however, a large majority (86\%) of all residents considered their drinking water safe.

The overall safety and satisfaction values with drinking water have declined from 91 to $86 \%$ over the past 10 years; however, a few people have specific health concerns with their drinking water. From a safety standpoint, public water providers and regulators have done an excellent job in the Pacific Northwest. There is, however, room for improvement in the areas of taste and water hardness as indicated by the widespread use of in-home water filters. The use of bottled water appears to have peaked at $34.4 \%$ in 2007 and has now declined to $26.5 \%$. This drop in the use of bottled water reaffirms the confidence of the urban public in public water suppliers.

In summary, the urban public has confidence that their drinking water supply in the Pacific Northwest is safe. This confidence could be increased further if public education on drinking water would become more proactive. Consequently, we propose the following three steps:

1. Provide educational opportunities so that public perceptions about drinking water quality match actual municipality monitoring data. Municipalities, state and local health organizations and university Extension should plan, work together and cooperate to make this effort successful.

2. Publicize the importance of the annual drinking water report (required by the SDWA) provided by local municipalities to the public using local television and print media.

3. Educate the public about the provisions of the Safe Drinking Water Act of 1974 (SDWA) and its major amendments in 1986 and 1996. Show how this legislation ensures that publically supplied water in urban areas is safe.

\section{ACKNOWLEDGEMENTS}

The authors thank USDA-NIFA for supporting this survey work over the last 12 years as a portion of the Pacific Northwest Water Resources Coordination Project. 


\section{REFERENCES}

[1] Gleick, P.H., The human right to water. Water Policy, 1(5), pp. 487-503, 1998.

[2] Chenoweth, J.L., Minimum water required for social and economic development. Desalination, 229, pp. 245-256, 2008. doi: http://dx.doi.org/10.1016/j.desal.2007.09.011

[3] Gleick, P.H., Basic water requirements for human activities: meeting basic needs. Water International, 21(2), pp. 83-92, 1996. doi: http://dx.doi.org/10.1080/02508069608686494

[4] Falkenmark, M., Fresh water - time for a modified approach. Ambio, 15, pp. 192-200, 1986.

[5] World Water Assessment Programme, Water for People, Water for Life: The United Nations World Water Development Report, UNESCO Publishing/Berghahn Books: Paris, 2003.

[6] WHO/UNICEF, Joint monitoring programme for water supply and sanitation, Global Water Supply and Sanitation Assessment 2000 Report, WHO/UNICEF: Washington, 2000.

[7] Howard, G. \& Bartram, J., Domestic Water Quantity, Service, Level and Health, World Health Organization: Geneva, 2003.

[8] Greenhalgh, A., Healthy living - water, BBC Health, March, 2001.

[9] Kalbermatten, J.M., Water and sanitation for all, will it become reality or remain a dream? Water International, 16, pp. 121-126, 1991. doi: http://dx.doi.org/10.1080/02508069108686104

[10] Dunlap, R.E., Trends in public opinion toward environmental issues: 1965-1990. Society \& Natural Resources, 4, pp. 285-312, 1991. doi: http://dx.doi.org/10.1080/08941929109380761

[11] Falahee, M. \& MacRae, A., Consumer appraisal of drinking water: multidimensional scaling analysis. Food Quality and Preference, 6, pp. 327-332, 1995. doi: http://dx.doi. org/10.1016/0950-3293(95)00035-6

[12] Fawell, J.K. \& Miller, D.G., Drinking water quality and the consumer. Journal of the Institution of Water and Environmental Management, 6, pp. 726-732, 1992. doi: http://dx.doi. org/10.1111/j.1747-6593.1992.tb00726.x

[13] Syme, G.J. \& Williams, K.D., The psychology of drinking water quality: and exploratory study. Water Resources Research, 29(12), pp. 4003-4010, 1993. doi: http://dx.doi. org/10.1029/93wr01933

[14] Dupont, D.P., Tapping into consumer perceptions of drinking water quality in Canada: capturing consumer demand to assist in better management of water resources. Canadian Water Resources Journal, 30(1), pp. 11-20, 2005. doi: http://dx.doi.org/10.4296/cwrj300111

[15] Krewski, D., Slovic, P., Bartlett, S., Flynn, J. \& Mertz, C.K., Health risk perception in Canada II: worldviews, attitudes and opinions. Human and Ecological Risk Assessment, 1(2), pp. 53-70, 1995.

[16] Means, E.G., Drinking water quality in the new millennium: the risk of underestimating public perception. Journal of the American Water Works Association, 94(8), pp. 28-33, 2002.

[17] Wright, J.A., Yang, H., Rivett, U. \& Gundrg, S.W., Public perception of drinking water safety in South Africa 2002-2009: a repeated cross-sectional study. BMC Public Health, 12, p. 556, 2012. doi: http://dx.doi.org/10.1186/1471-2458-12-556

[18] Doria, M., Factors influencing public perception of drinking water quality. Water Policy, 12, pp. 1-19, 2010. doi: http://dx.doi.org/10.2166/wp.2009.051

[19] Doria, M., Pidgeon, N. \& Hunter, P.R., Perceptions of drinking water quality and risk and its effect on behavior: a cross national study. Science of the Total Environment, 407(21), pp. 5455-5464, 2009. doi: http://dx.doi.org/10.1016/j.scitotenv.2009.06.031

[20] McGuire, M.J., Off-flavor as the consumers' measure of drinking water quality. Water Science and Technology, 31(11), pp. 1-8, 1995. doi: http://dx.doi.org/10.1016/0273-1223(95)00448-v

[21] Dunlap, R.E. \& Scarce, R., Poll trends: environmental problems and protection. The Public Opinion Quarterly, 55(4), pp. 651-672, 1991. doi: http://dx.doi.org/10.1086/269288 
[22] Mahler, R.L., Simmons, R. \& Sorensen, F., Drinking water issues in the Pacific Northwest. Journal of Extension, 43(6), 6RIB6, available at www.joe.org/joe/2005december/rb6.shtml, 2005.

[23] Ross, V., The determinants of trust and satisfaction with drinking water quality. ARCWIS Occasional Paper, 2005.

[24] Tyler, T.R. \& Degoey, P., Trust in organizational authorities. Trust in Organizations, Frontiers of Theory and Research, eds. R.M. Kramer \& T.R. Tyler, Sage: London, 1996

[25] Doria, M., Bottled water versus tap water: understanding consumers-preferences. Journal of Water Health, 2006, pp. 271-276, 2006.

[26] Hu, Z., Morton, L.W. \& Mahler, R.L., Bottled water: United States consumers and their perceptions of water quality. International Journal of Environmental Research and Public Health, 8, pp. 565-578, 2011. doi: http://dx.doi.org/10.3390/ijerph8020565

[27] Levallois, P., Grondin, J. \& Gingras, S., Evaluation of consumer attitudes on taste and tap water alternatives in Quebec. Water Science and Technology, 40(6), pp. 135-139, 1999. doi: http:// dx.doi.org/10.1016/s0273-1223(99)00549-1

[28] Faure, M.G., The EC Directive on Drinking Water: Institutional Aspects, Springer: The Netherlands, 87 pp., 1994.

[29] Biswas, A.K., Water management for major urban centres. Water Resources Development, 22(2), pp. 183-197, 2006. doi: http://dx.doi.org/10.1080/07900620600690789

[30] Johnson, B.B., Do reports on drinking water affect customers' concerns? Experiments in report content. Risk Analysis, 23(5), pp. 985-998, 2003. doi: http://dx.doi.org/10.1111/15396924.00375

[31] Carter, L.W., Nelson, D.I. \& Everett, J.W., Public perceptions of water quality risks - influencing factors and enhanced opportunities, Journal of Environmental Systems, 22(2), pp. 163-187, 1992. doi: http://dx.doi.org/10.2190/93d9-jf0n-eef8-w4pw

[32] Mahler, R.L., Simmons, R., Sorensen, F. \& Miner, J.R., Priority water issues in the Pacific Northwest. Journal of Extension, 42(5), Article 5RIB3, available at http://www.joe.org/ joe/2004october/rb3.php, 2004.

[33] Mahler, R.L., Smolen, M.D., Borisova, T., Boellstorff, D.E., Adams, D.C. \& Sochacka, N.W., The national water survey needs assessment program. Natural Sciences Education, 42(1), pp. 98-103, 2013.

[34] Salent, P. \& Dillman, D., How to Conduct Your Own Survey, John Wiley and Sons, Inc.: New York, 1994.

[35] Dillman, D., Mail and Internet Surveys: The Tailored Design Method. John Wiley and Sons, Inc.: New York, 2000.

[36] Mahler, R.L., Gamroth, M., Pearson, P., Sorenson, F., Barber, M.E. \& Simmons, R., Information sources, learning opportunities and priority water issues in the Pacific Northwest. Journal of Extension, 48(2), Article 2RIB2, available at: http://www.joe.org/joe/2010april/rb2.php, 2010.

[37] SAS Institute Inc., SAS Online Document 9.1.3. Cary, SAS Institute Inc.: North Carolina, 2004.

[38] Mahler, R., Barber, M. \& Shafii, B., Drinking water issues and concerns of urban residents of the Pacific Northwest, USA. WIT Transactions on the Built Environment, 139, ISSN 17433509, 2014. doi: http://dx.doi.org/10.2495/uw140171 